\title{
PROTEIN DAN ASAM AMINO PADA EDIBLE Sargassum aquifolium, Ulva lactuca, DAN Gracilariopsis longissima
}

\author{
Alberta Rika Pratiwi, Irma Fadlilah, Victoria Kristina Ananingsih, Meiliana \\ Fakultas Teknologi Pertanian, Universitas Katolik Soegijapranata Semarang \\ Jalan Pawiyatan Luhur IV/1, Bendan Dhuwur, Semarang 50234
}

Diterima: 14 Agustus 2021/Disetujui: 12 November 2021

*Korespondensi: pratiwi@unika.ac.id

Cara sitasi: Pratiwi AR, Fadlilah I, Ananingsih VK, Meiliana. 2021. Protein dan asam amino pada edible Sargassum aquifolium, Ulva lactuca, dan Gracilariopsis longissima. Jurnal Pengolahan Hasil Perikanan Indonesia. 24(3): 337-346.

\begin{abstract}
Abstrak
Makroalga telah digunakan industri pangan sejak lama karena komponen yang dikandungnya misalnya alginat, karagenan, dan agar. Selain itu alga mengandung nutrisi dan komponen bioaktif lainnya sebagai pangan fungsional. Kandungan protein dan keragaman jenis asam amino dapat menjadi informasi penting untuk memaksimalkan potensi yang dimiliki alga. Penelitian ini bertujuan mengetahui kandungan protein dan profil asam amino pada S.aquifolium, U. lactuca, dan G. longissima. Ekstraksi protein menggunakan pelarut 0,4 $\mathrm{M} \mathrm{NaOH}$ dan ultrasonikasi 5 menit dengan amplitudo 70\%. Analisis kandungan protein menggunakan metode Bradford. Komposisi asam amino dianalisis menggunakan ultra performance liquid chromatography. Protein tertinggi di antara ketiga makroalga tersebut adalah S. aquifolium yakni mengandung protein 4,17\% dan teridentifikasi 16 jenis asam amino dengan 10 jenis asam amino esensial (AAE) dan 6 asam amino non esensial (AANE). U lactuca teridentifikasi 9 AAE dan 6 AANE. Untuk G. longissima teridentifikasi 8 jenis AAE dan 6 jenis AANE. Asam glutamat merupakan asam amino tertinggi pada $S$. aquifolium sebesar $400,27 \pm 62,27 \mathrm{mg} / \mathrm{kg}$, sedangkan pada $U$. lactuca dan

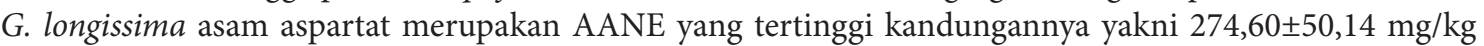
dan $435,57 \pm 25,81 \mathrm{mg} / \mathrm{kg}$. Edible makroalga tersebut mengandung protein dan asam amino yang penting dan beberapa memiliki konsentrasi lebih tinggi dibandingkan sumber protein makroalga sejenis dari perairan lain. Asam amino yang dimiliki ketiga makroalga ini memiliki potensi untuk dikembangkan lebih lanjut menjadi produk pangan berbasis tanaman dengan karakter flavor dan rasa umami.
\end{abstract}

Kata kunci: asam amino, edible macroalga, protein,

\section{Protein and Amino Acid of Edible Sargassum aquifolium, Ulva lactuca and Gracilariopsis longissima}

\begin{abstract}
Seaweed or macroalgae have been used by the food industry for a long time because of the components they contain such as alginate, carrageenan, and agar. In addition, seaweed contains nutrients and other bioactive components which makes seaweed a functional food. Information about its protein content and amino acid diversity is important to maximize seaweed's potential. This study aimed to determine the protein content and amino acid profile of S. aquifolium, U. lactuca, and G. longissima. Protein was extracted using $0.4 \mathrm{M} \mathrm{NaOH}$ solvent and ultrasonication for 5 minutes with an amplitude of $70 \%$ and analyzed with the Bradford method. The amino acid composition was analyzed using ultra performance liquid chromatography. S. aquifolium had the highest protein content (4.17\%) and 16 types of amino acids, which consist of 10 essential amino acids (AAEs) and 6 non-essential amino acids (AANEs). U. lactuca had 9 AAEs and 6 AANEs, while G. longissima had 8 types of AAEs and 6 types of AANEs. Glutamic acid was the highest amino acid in S. aquifolium $(400.27 \pm 62.27 \mathrm{mg} / \mathrm{kg})$, while aspartic acid was the highest in
\end{abstract}


U. lactuca $(274.60 \pm 50.14 \mathrm{mg} / \mathrm{kg})$ and G. longissima $(435.57 \pm 25.81 \mathrm{mg} / \mathrm{kg})$. Edible macroalgae contain protein and many types of amino acids, and some have higher concentrations than similar macroalgae protein sources from other water areas. The amino acids possessed by these three macroalgae have the potential to be further developed into plant-based food products with umami flavor and taste characteristics, such as vegetables, spices, or any processed food products.

Keyword: amino acids, edible macroalgae, protein

\section{PENDAHULUAN}

Makroalga telah digunakan pada industri pangan karena komponen di dalamnya yakni algin, karagenan, dan agar. Selain sebagai bahan makanan, makroalga juga digunakan sebagai bahan kosmetik dan farmasi (Hardouin et al. 2014). Makroalga diketahui mengandung karbohidrat, protein, lemak, vitamin, polifenol, dan mineral. Komposisi nutrisi dan komponen biokimia makroalga bervariasi berdasarkan spesiesnya. Selain itu juga oleh tahap perkembangan, faktor lingkungan, faktor geografi, habitat, dan musim panen (Chan \& Matanjun 2016; Pangestuti \& Kim 2015; Vieira et al. 2018). Secara khusus protein makroalga memiliki kandungan tinggi antara 2,53-5,48\% (Gazali et al. 2018; Nufus et al. 2017). Protein tersebut mengandung asam amino,yang dapat berkontribusi pada industri pangan dan kesehatan. Beberapa penelitian makroalga dengan berbagai kondisi geografi menghasilkan keragaman jenis asam amino yang dimiliki yang dapat dikelompokkan ke dalam asam amino esensial dan non esensial (Kazir et al. 2018; Chan \& Matanjun 2016). Hasil penelitian Kazir et al. (2018) Ulva sp. mengandung alanina, arginina, asam aspartat, asam glutamat, glisina, histidina, isoleusina, leusina, lisina, metionina, fenilalanina, prolina, serina, treonina, tirosina, valina. Makroalga juga mengandung peptida atau protein pendek dengan 2-20 asam amino dan menjadi aktif saat dilepaskan melalui proses hidrolisis dengan enzim dan fermentasi. Peptida bioaktif ini dapat berfungsi sebagai modulator berbagai proses di dalam tubuh, antihipertensi, antibakteri, antioksidan (Harnedy \& Richard 2011; Seca \& Pinto 2018).

Sargassum sp, Ulva sp., dan Gracilariopsis sp. merupakan jenis makroalga yang dapat dikonsumsi manusia atau edible macroalgae (Debbarma et al. 2016). Penelitian mengenai kandungan protein dan profil asam amino S. aquifolium, U. lactuca, dan G. longissima dari Pantai Sayang Heulang Garut, Jawa Barat diharapkan dapat digunakan sebagai informasi penting dalam pemanfaatan makroalga sebagai bahan pangan fungsional dan bidang industri pangan lainnya. Berdasarkan latar belakang tersebut di atas, maka tujuan dari penelitian ini adalah menentukan kandungan protein dan jenis asam aminonya dari tiga makroalga yang dikonsumsi yakni S. aquifolium, U. lactuca, G. longissima.

\section{BAHAN DAN METODE Bahan dan Alat}

Bahan utama adalah makroalga S. aquifolium, U. lactuca, dan G. longissima dari Pantai Sayang Heulang Garut, Jawa Barat. Sampel makroalga tersebut diidentifikasi ke dalam jenisnya oleh Pusat Penelitian Oseanografi-Badan Riset dan Inovasi Nasional (BRIN). Bahan kimia yang digunakan $\mathrm{HCl}$ PA (Merck), etanol 96\% PA (Merck), metanol (Merck), asam fosfat $85 \%$ (Merck), $\mathrm{NaOH}$ (Merck), coomassie brilliant blue (Merck), bovine serum albumin (Merck), standar asam amino (Sigma Aldrich).

Alat yang digunakan dalam analisis meliputi sentrifugasi sejuk/refrigerated centrifuge (Sigma), pnegolah ultrasonik (Hielscher), spektrofotometer (Shimadzu) dan Acquity UPLC (Ultra Performance Liquid Chromatography) H Class with PDA Detector Waters 2012.

\section{Metode \\ Ekstraksi dan analisis protein}

Metode ekstraksi protein mengacu pada Kadam (2016) yang dimodifikasi. Sampel kering makroalga sebanyak $70 \mathrm{mg}$ dilarutkan dalam 1,4 mL akuabides dan diinkubasi pada suhu $4^{\circ} \mathrm{C}$ selama 16 jam. Setelah inkubasi, disentrifugasi $9.000 \mathrm{rpm}, 20$ menit, $4^{\circ} \mathrm{C}$. 
Endapan yang diperoleh dilarutkan ke dalam $0,4 \mathrm{M} \mathrm{NaOH}$ dan disentrifugasi kembali 9.000 rpm, 20 menit, $4^{\circ} \mathrm{C}$. Filtrat yang diperoleh dilanjutkan dengan ultrasonikasi (ultrasound processor) 5 menit dengan amplitudo $70 \%$ dan cycle 0,5. Setelah itu analisis kadar protein dilakukan berdasarkan metode Bradford (1976) dengan standar BSA.

\section{Prosedur pengujian protein}

Pengukuran kadar protein menggunakan prosedur Bradford (1976), diawali dengan pembuatan standar BSA. Larutan standar yang digunakan adalah BSA. Sebanyak $1 \mathrm{mg}$ BSA diencerkan menggunakan $\mathrm{ddH}_{2} \mathrm{O}$ menjadi deret konsentrasi 40, 80, 120, 160 dan 200 ppm, kemudian ditambah dengan larutan Bradford dan diamati absorbansinya menggunakan panjang gelombang 595. Selanjutnya dibuat kurva standar BSA untuk dasar penghitungan konsentrasi protein. Pengukuran kadar protein sampel dilakukan terhadap hasil ekstraksi ketiga sampel makroalga. Sebanyak $2 \mathrm{uL}$ sampel ditambah reagen Bradford dan $\mathrm{ddH}_{2} \mathrm{O}$, diukur absorbansinya menggunakan spektrofotometri dengan panjang gelombang 595. Selanjutnya kadar protein ditentukan menggunakan rumus linier yang diperoleh dari kurva standar BSA. Rumus tersebut adalah:

$\mathrm{Y}=0,0046 \mathrm{x}+0,0171$

$\mathrm{Y}$ adalah nilai absorbansi yang diperoleh

$\mathrm{X}$ adalah kadar protein yang dicari.

\section{Analisis asam amino}

Analisis asam amino meliputi jenis dan konsentrasinya dilakukan menggunakan acuan Waters (2012). Filtrat ekstraksi protein yang diperoleh dilanjutkan analisis asam amino menggunakan UPLC dengan kolom C18, fase-fase gerak: Eluen Accq. Tag Ultra; akuabides, sistem pompa: gradien, suhu kolom $49^{\circ} \mathrm{C}$; detektor: PDA (Waters 2012). Penghitungan kadar asam amino dalam sampel dengan menggunakan perbandingan (rasio) area analit dengan internal standar, dihitung menggunakan rumus sebagai berikut:

Rasio standar atau sampel $(\mathrm{RS})=\frac{\text { Aspl }}{\text { AIS }}$

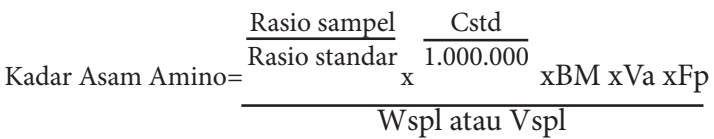

Keterangan:

Kadar Asam Amino (mg/Kg; mg/L);

A spl = Luas area analit asam amino

A IS = Luas area internal standard

C Std $=$ Konsentrasi larutan standar asam amino

$(\mathrm{pmol} / \mu \mathrm{L})$

$\mathrm{BM}=$ Bobot molekul asam amino

$\mathrm{Va}=$ Volume akhir sampel $(\mu \mathrm{L})$

$\mathrm{Fp}=$ Faktor pengenceran

$\mathrm{W}$ spl = Bobot penimbangan sampel $(\mathrm{g})$

$\mathrm{V}$ spl $=$ Volume pemipetan sampel $(\mathrm{mL})$

\section{Analisis Data}

Pengujian kandungan protein dan asam amino dilakukan ulangan sebanyak tiga kali. Hasil yang diperoleh selanjutnya dianalisis secara deskriptif untuk melihat secara kuantitif protein dan asam amino yang teridentifikasi pada tiga makroalga edible dalam penelitian ini. Data kuantatif disajikan dalam bentuk rata-rata dengan standar deviasi.

\section{HASIL DAN PEMBAHASAN Kandungan Protein}

Protein makroalga dapat menjadi dapat menjadi alternatif sumber protein nabati yang mengandung asam amino esensial dan non esensial. Hasil analisis kadar protein dapat dilihat pada Table 1.

Table 1 Protein concentration in edible macroalgae

\begin{tabular}{lr}
\hline \multicolumn{1}{c}{ Macroalgae } & Protein $(\%)$ \\
\hline S. aquifolium & $4.17 \pm 0.16$ \\
U. lactuca & $3.07 \pm 0.05$ \\
G. longissima & $3.55 \pm 0.18$ \\
\hline
\end{tabular}

Table 1 menunjukkan kandungan protein yang berbeda meskipun tidak sangat signifikan. Kandungan protein ketiga makroalga berkisar 3,07-4,17\%. Protein makroalga memang lebih kecil dibandingkan dengan mikroalga. Hal ini dibuktikan dari beberapa penelitian protein makroalga untuk jenis berbeda dan wilayah perairan yang berbeda sekalipun juga menunjukkan kisaran yang sama. S. polycystum asal perairan Pulau Pramuka, Kepulauan Seribu 3,64\% (Diachanty 
et al. 2017) dan U. lactuca 5,14\% (Nufus et al. 2017), dari Pantai Lemito, Gorontalo 3,65\% (Manteu et al. 2018). Purwaningsih \& Deskawati (2020) juga melaporkan bahwa protein Gracilaria sp. dari tambak di Banten sebesar 9,36\%. Adanya perbedaan kecil memang dapat terjadi meskipun tidak signifikan, hal ini disebabkan karena jenis spesies dan habitat yang berbeda. Makroalga seluruh talusnya melakukan fotosintesis dan substrat perairannya, maka jika tumbuh di habitat atau perairan berbeda dapat memengaruhi kandungan biokimianya (Chan \& Matanjun (2016); Kadam et al. (2015), Vieira et al. (2018)).

\section{Profil Asam Amino}

Analisis asam amino merupakan langkah awal yang digunakan untuk memberikan informasi jenis dan kadar asam amino pada rumput laut. Komposisi asam amino makroalga diukur menggunakan UPLC.
Terdapat 16 jenis asam amino yang terdeteksi dengan komposisi yang berbeda-beda pada ketiga makroalga yang diteliti. Dalam penelitian ini, teridentifikasi 16 jenis asam amino pada S. aquifolium, 15 jenis pada U. lactuca, dan 14 jenis asam amino pada G. longissima (Table 2).

Semua makroalga yang digunakan pada penelitian ini mengandung asam amino esensial (AAE). Total AAE yang dimiliki S. aquifolium adalah $1.218,25 \pm 98,29 \mathrm{mg} / \mathrm{L}$ atau $1,22 \pm 0,09 \mathrm{~g} / \mathrm{L}, \quad U$. lactuca adalah $883 \pm 120,42 \mathrm{mg} / \mathrm{L}$ atau $0,88 \pm 0,12 \mathrm{~g} / \mathrm{L}$, dan G. longissima adalah $1.726 \pm 42,55 \mathrm{mg} / \mathrm{L}$ atau $1,73 \pm 0,04 \mathrm{~g} / \mathrm{L}$. Table 3 menunjukkan bahwa kandungan asam amino treonina, leusina, lisina, valina, isoleusina, fenilalanina yang dimiliki S. aquifolium, U. lactuca, dan G. longissima lebih tinggidibandingkandengan rekomendasi asupan harian berdasarkan Food and Agriculture Organization of the United Nations (FAO) dan The World Health

Table 2 Types of identified amino acids and their concentrations $(\mathrm{mg} / \mathrm{L})$ in edible maroalgae

\begin{tabular}{|c|c|c|c|}
\hline Types of amino acid & S. aquifolium & U. lactuca & G. longissima \\
\hline Threonine ${ }^{*}$ & $116.65 \pm 11.39$ & $99.22 \pm 11.27$ & $185.14 \pm 6.56$ \\
\hline Tyrosine ${ }^{\star}$ & $112.86 \pm 3.69$ & $64.55 \pm 18.25$ & $131.82 \pm 4.71$ \\
\hline Leusin $e^{\star}$ & $220.15 \pm 23.15$ & $163.05 \pm 39.18$ & $289.74 \pm 18.37$ \\
\hline Lysine* & $127.10 \pm 19.15$ & $73.70 \pm 16.77$ & $154.12 \pm 12.20$ \\
\hline Arginine ${ }^{*}$ & $143.71 \pm 11.30$ & $153.25 \pm 14.7$ & $235.47 \pm 11.12$ \\
\hline Valine* & $148.27 \pm 17.06$ & $128.39 \pm 17.62$ & $232.67 \pm 11.64$ \\
\hline Isoleucine $e^{*}$ & $117.85 \pm 13.69$ & $86.83 \pm 13.62$ & $193.35 \pm 7.72$ \\
\hline Phenylalanine ${ }^{\star}$ & $175.81 \pm 3.43$ & $161.68 \pm 20.20$ & $304.69 \pm 7.69$ \\
\hline Methionine* & $55.86 \pm 5.19$ & $8.45 \pm 14.63$ & $\mathrm{ND}$ \\
\hline Cysteine ${ }^{\star}$ & ND & ND & $\mathrm{ND}$ \\
\hline Histidine $^{*}$ & $50.21 \pm 1.57$ & ND & ND \\
\hline Tryptophan* & ND & ND & ND \\
\hline Proline & $178.45 \pm 15.63$ & $155.91 \pm 21.66$ & $235.80 \pm 1.30$ \\
\hline Aspartic Acid & $303.67 \pm 52.09$ & $274.60 \pm 50.14$ & $435.57 \pm 25.81$ \\
\hline Glycine & $173.33 \pm 16.58$ & $153.25 \pm 14.7$ & $279.03 \pm 8.50$ \\
\hline Alanine & $218.52 \pm 24.86$ & $247.20 \pm 38.47$ & $285.77 \pm 7.75$ \\
\hline Glutamic Acid & $400.27 \pm 62.27$ & $240.33 \pm 44.87$ & $430.83 \pm 19.44$ \\
\hline Serine & $143.49 \pm 11.65$ & $152.78 \pm 14.14$ & $430.83 \pm 19.44$ \\
\hline Total of amino acid & $1,218.25 \pm 98.29$ & $883 \pm 120.42$ & $1,726 \pm 42.55$ \\
\hline
\end{tabular}

Note: ${ }^{*}$ essential amino acid; ND $=$ not detected 
Table 3 Concentration of essential amino acids (mg/L) in S. aquifolium, U. lactuca, G. longissima compared to WHO/FAO daily intake recommendation data (2007)

\begin{tabular}{lrrrr}
\hline $\begin{array}{c}\text { Essential amino } \\
\text { acid }\end{array}$ & $\begin{array}{c}\text { S. aquifolium } \\
(\mathrm{mg} / \mathrm{L})\end{array}$ & \multicolumn{1}{c}{$\begin{array}{c}\text { U. lactuca } \\
(\mathrm{mg} / \mathrm{L})\end{array}$} & $\begin{array}{c}\text { G. longissima } \\
(\mathrm{mg} / \mathrm{L})\end{array}$ & $\begin{array}{c}\text { WHO/FAO } \\
(2007)(\mathrm{mg} / \mathrm{kg})\end{array}$ \\
\hline Threonine $^{*}$ & $116.65 \pm 11.39$ & $99.22 \pm 11.27$ & $185.14 \pm 6.56$ & 15.00 \\
Leusine $^{*}$ & $220.15 \pm 23.15$ & $163.05 \pm 39.18$ & $289.74 \pm 18.37$ & 39.00 \\
Lysine $^{*}$ & $127.10 \pm 19.15$ & $73.70 \pm 16.77$ & $154.12 \pm 12.20$ & 30.00 \\
Valine $^{*}$ & $148.27 \pm 17.06$ & $128.39 \pm 17.62$ & $232.67 \pm 11.64$ & 26.00 \\
Isoleucine $^{*}$ & $117.85 \pm 13.69$ & $86.83 \pm 13.62$ & $193.35 \pm 7.72$ & 20.00 \\
Phenylalanine $^{*}$ & $175.81 \pm 3.43$ & $161.68 \pm 20.20$ & $304.69 \pm 7.69$ & 25.00 \\
Methionine $^{*}$ & $55.86 \pm 5.19$ & $8.45 \pm 14.63$ & $\mathrm{ND}$ & 10.00 \\
Cysteine $^{*}$ & $\mathrm{ND}$ & $\mathrm{ND}$ & $\mathrm{ND}$ & 4.00 \\
Histidine $^{*}$ & $50.21 \pm 1.57$ & $\mathrm{ND}$ & $\mathrm{ND}$ & 10.00 \\
Tryptophan $^{*}$ & $\mathrm{ND}$ & $\mathrm{ND}$ & $\mathrm{ND}$ & 4.00 \\
\hline ND $=$ not detected & & & &
\end{tabular}

Organization (WHO), yaitu lisina $0,03 \mathrm{~g} / \mathrm{kg}$; leusina $0,04 \mathrm{~g} / \mathrm{kg}$; isoleusina $0,02 \mathrm{~g} / \mathrm{kg}$; valina $0,036 \mathrm{~g} / \mathrm{kg}$; treonina $0,15 \mathrm{~g} / \mathrm{kg}$; histidina 0,01 $\mathrm{g} / \mathrm{kg}$; fenilalanina $0,03 \mathrm{~g} / \mathrm{kg}$ dan metionina $0,01 \mathrm{~g} / \mathrm{kg}$ (Mišurcová et al. 2013).

Leusina merupakan AAE paling tinggi yang terdapat pada $S$. aquifolium $(220,15 \pm$ $23,15 \mathrm{mg} / \mathrm{L})$ dan U. lactuca $(163,05 \pm 39,18$ $\mathrm{mg} / \mathrm{L}$ ), dan AAE tertinggi kedua pada $G$. longissima $(289,74 \pm 18,37 \mathrm{mg} / \mathrm{L})$. Jumlah tersebut lebih tinggi dibandingkan bahan pangan lainnya, misalnya kedelai, semangka dan timun (42-47,17 mg/kg) (Corleto et al. 2019; Song et al. 2013). Leusina sebagai suplemen dapat menurunkan asupan makanan melalui efek kenyang dan menurunkan adipositas melalui penurunan ekspresi fatty acid synthase (FAS) pada jaringan adiposa dan peningkatan oksidasi asam lemak pada sel otot $\mathrm{C} 2 \mathrm{C} 12$ (McAllan et al. 2013). Leusina bermanfaat bagi anak-anak yang sedang mengalami pertumbuhan dan perbaikan kondisi wasting (Jacoeb et al. 2012; Wamiti et al.2018), maupun bagi orang dewasa dan remaja dengan cerebral palsy untuk peningkatan kekuatan dan massa otot (Theis et al. 2021). Leusina juga berfungsi mengurangi ekspresi penanda neuroinflamasi setelah cedera otak traumatis (Hegdekar et al. 2021).

Fenilalanina $\quad(304,69 \pm 7,69 \quad \mathrm{mg} / \mathrm{L})$ merupakan AAE yang paling banyak ditemukan pada G. longissima. Hasil serupa juga ditemukan pada G. gracilis dari perairan Sulawesi Selatan $(7,52 \mathrm{~g} / \mathrm{kg})$ dan G. salicornia dari Nusa Tenggara Barat (17,94 mg/g) (Lumbessy et al. 2019; Rasyid et al. 2019). Fenilalanina berperan pada biosintesis dopamin, noradrenalin, dan adrenalin untuk mengatasi depresi, artritis reumatoid, osteoartritis, sklerosis ganda, penyakit Parkinson, dan attention deficit hyperactivity disorder/ADHD (Akram et al. 2020). Selain itu, fenilalanina berperan dalam peningkatan produksi hormon tiroksin untuk peningkatan metabolisme basal dan pengaturan suhu tubuh (Afifudin et al. 2014).

Konsentrasi AAE arginina pada G. longissima $(235,47 \pm 11,12 \mathrm{mg} / \mathrm{L}) \quad$ juga lebih banyak dibandingkan dengan dua makroalga lainnya. AAE arginina berfungsi dalam meningkatkan produksi hormon pertumbuhan, meningkatkan kesuburan pria (Purwaningsih et al. 2013), membantu penyembuhan luka, berperan dalam respons metabolik, dan imunitas (Morris et al. 2017; Utari et al. 2011) melalui pembentukan nitrat oksida (NO) dari arginina yang membantu sintesis kolagen pada luka. NO juga berperan dalam metabolisme glukosa, asam lemak, dan asam amino.

G. longissima, S. aquifolium, dan U. lactuca mengandung branched-chain amino acids (BCAAs), yaitu leusina, isoleusina, dan valina. Kadar BCAAs pada G. longissima lebih tinggi 
dibandingkan dua rumput laut lainnya, dengan kadar valina sebesar 232,67 $\pm 11,64$ $\mathrm{mg} / \mathrm{L}$ dan kadar isoleusina 193,35 $\pm 7,72$ $\mathrm{mg} / \mathrm{L}$. BCAAs memiliki efek penghematan protein atau protein-sparing effect pada masa pemulihan (recovery) setelah olahraga sehingga kerusakan otot dapat dikontrol dan diminimalkan (Kim et al. 2013), serta dapat memperbaiki fungsi hati pada pasien dengan gangguan liver (Shu et al. 2014).

Tidak banyak ditemukan AAE yang mengandung sulfur pada ketiga jenis rumput laut ini. Hasil penelitian menunjukkan bahwa sisteina tidak terdeteksi pada ketiga jenis rumput laut ini, sedangkan S. longissima dan U. lactuca memiliki metionina dengan konsentrasi yang kecil. Metionina dapat ditemukan dalam jumlah yang lebih banyak pada sumber pangan hewani. Metionina berperan besar dalam fungsi normal sel dan juga merupakan prekursor sisteina yang digunakan untuk membentuk beberapa molekul penting seperti glutation (antioksidan yang diproduksi alami di dalam tubuh) yang mencegah pembentukan plak pada pembuluh darah (Sena et al. 2013) dan taurina yang membantu keseimbangan elektrolit di dalam tubuh (Ripps \& Shen 2012). Beberapa penelitian menunjukkan bahwa diet yang rendah kadar metionina dapat menghambat pertumbuhan sel kanker (Cavuoto \& Fenech 2012).

Ketiga rumput laut ini juga mengandung lisina yang memiliki fungsi penting dalam pertumbuhan sel normal dan metabolisme (Yang et al. 2016) dan treonina yang penting dalam pemeliharaan mukosa usus (Mao et al. 2011). Selain itu, ditemukan juga tirosina yang berperan sebagai antioksidan yang tinggi terhadap radikal peroksi (Matsui et al. 2018). Genus Gracilaria pada umumnya memiliki treonina dan tirosina yang tinggi, seperti G. gracilis dari perairan Sulawesi Selatan $(7,34 \mathrm{~g} / \mathrm{kg}$ dan $2,15 \mathrm{~g} / \mathrm{kg})$ dan $G$. salicornia dari Nusa Tenggara Barat $(22,51$ $\mathrm{mg} / \mathrm{g}$ dan 17,40 mg/g) (Lumbessy et al. 2019; Rasyid et al. 2019). Histidina yang juga berfungsi sebagai antioksidan hanya dijumpai pada S. aquifolium $(50,21 \mathrm{mg} / \mathrm{L})$. Suplementasi histidina dapat menghambat kerusakan oksidatif oleh paparan Cu di usus (Jiang et al.2016; Kopec et al. 2020).

\section{Asam Amino Pencetus Rasa Umami (Umami Enhancer)}

Asam amino non esensial yang dimiliki oleh ketiga rumput laut yang diteliti difokuskan pada kandungan asam glutamat dan asam aspartat. Hasil pengujian didapatkan pada S. aquifolium, U. lactuca, G. longissima menunjukkan kadar asam amino asam aspartat yang tinggi yaitu $303,67 \pm 52,09$ $\mathrm{mg} / \mathrm{L} ; 274,60 \pm 50,14 \mathrm{mg} / \mathrm{L} ; 435,57 \pm 25,81 \mathrm{mg} / \mathrm{L}$, sementara asam glutamat sebesar $400,27 \pm 62,27$ $\mathrm{mg} / \mathrm{L} ; 240,33 \pm 44,87 \mathrm{mg} / \mathrm{L}$ dan $430,83 \pm 19,44$ $\mathrm{mg} / \mathrm{L}$. Konsentrasi tersebut jauh lebih tinggi bila dibandingkan dengan jenis yang lain misalnya pada penelitian Farid et al. (2013) diketahui Gracilaria verrucosa memiliki kadar asam glutamat kurang dari 0,02 ppm atau 0,02 $\mathrm{mg} / \mathrm{kg}$ ), tetapi apabila dibandingkan dengan Gracilaria gracilis baik asam aspartat maupun asam glutamat ternyata lebih lebih kecil (Rasyid et al. 2019). Hasil penelitian Kazir et al. (2018) menunjukkan bahwa kadar asam aspartat Ulva sp. dan Gracilaria sp. dari Haifa, Israel yaitu $16,11 \%$ dan $12,81 \%$. Kadar asam glutamat Ulva sp. dan Gracilaria sp. yaitu $12 \%$ dan 13\%. Peng et al. (2013) melaporkan bahwa kandungan asam aspartat Sargassum naozhouense sebesar 8,39 g/100 g protein, glutamic acid 13,21 g/100 g protein.

Keberadaan asam glutamat dan asam aspartat pada makroalga dengan konsentrasi tinggi akan menjadi bahan yang dipertimbangkan dalam pengembangan flavor enhancer terutama umami atau produk dengan karakteristik berbasis tanaman misalnya pada plant-based meat product (Cofrades et al. 2017). Produk-produk tersebut dapat menjawab kebutuhan para vegetarian yang terus meningkat seiring kebutuhan akan makanan sehat. Selain kandungan gizi lainnya, tingginya konsentrasi asam aspartat dan asam glutamat ternyata berperan memberikan flavor dan taste pada makroalga (Mohd Rosni et al. 2015), sedangkan menurut Mišurcová et al. (2013), asam aspartat, asam glutamat bersama alanina dan glisina berperan sebagai komponen utama flavor 
pada makroalga. Bahan yang memiliki flavor dan taste ini, dapat pula memberikan rasa umami dalam produk makanan (Pangestuti \& Kim 2015; Yaich et al. 2011).

\section{KESIMPULAN}

Kandungan protein ketiga rumput laut (edible makroalga) menunjukkan kadar protein yang kecil yakni antara 3-4\%. Jenis asam amino yang teridentifikasi terdiri dari AAE dan AANE. Terdapat 8 sampai 10 jenis AAE dan 6 jenis AANE yang dapat ditemukan di ketiga edible macroalgae tersebut. Dari aspek jenis dan konsentrasi asam amino AAE yang dimiliki oleh ketiga edible macroalgae, dapat menjadi sumber zat gizi dengan kualitas yang tinggi dan sumber pangan fungsional potensial. AANE khususnya asam glutamat dan asam aspartat memiliki konsentrasi yang tinggi ditemukan di ketiga makroalga. Berdasarkan besaran konsentrasi kedua asam amino tersebut dimungkinkan memiliki potensi untuk pengembangan lebih lanjut menjadi produk pangan berbasis alga dengan karakter flavor dan taste umami.

\section{UCAPAN TERIMA KASIH}

Terima kasih diucapkan kepada Direktorat Riset dan Pengabdian Masyarakat, Direktorat Jenderal Penguatan Riset dan Pengembangan atas Hibah Penelitian Strategis Nasional Institusi, Ristekdikti, Tahun 2019, No. SK 010/ L6/AK/SP2H.1/PENELITIAN/2019.

\section{DAFTAR PUSTAKA}

Akram M, Daniyal M, Ali A, Zainab R, Syed MAS, Munir N, Tahir IM. 2020. Role of Phenylalanine and Its Metabolites in Health and Neurological Disorders. Di dalam: Synucleins - Biochemistry and Role in Diseases. Rijeka (HR): IntechOpen.

AfifudinI K, Suseno SH, Jacoeb AM. 2014. Profil asam lemak dan asam amino gonad bulu babi. Jurnal Pengolahan Hasil Perikanan Indonesia.17(1): 60-70.

Bradford NA. 1976. A rapid and sensitive method for the quantitation of microgram quantities of protein utilizing the principle of protein-dye binding.
Analytical Biochemistry. 72: 248-254.

Cavuoto P, Fenech MF. 2012. A review of methionine dependency and the role of methionine restriction in cancer growth control and life-span extension. Cancer treatment reviews. 38(6):726-736.

Chan PT, Matanjun P. 2016. Chemical composition and physicochemical properties of tropical red seaweed, Gracilaria changii. Food Chemistry. 221:302-310.

Chasanah E, Nurilmala M, Purnamasari AR, Fithriani D. 2015. Komposisi kimia, kadar albumin dan bioaktivitas ekstrak protein ikan gabus (Channa striata) alam dan hasil budidaya. Jurnal Pascapanen dan Bioteknologi Kelautan dan Perikanan. 10(2): 123-132.

Cofrades S, Benedi J, Garcimartin A, SanchezMuniz F, Jimenez-Colmenero F. 2017. A comprehensive approach to formulation of seaweed enriched meat product: From technological development to assessment of healthy properties. Food research international. 99: 1084-1094.

Corleto K A, Singh J, Jayaprakasha GK, Patil BS. 2019. A sensitive HPLC-FLD method combined with multivariate analysis for the determination of amino acids in L-citrulline rich vegetables. Journal of Food and Drug Analysis. 27(3): 717-728.

Debbarma J,Rao BM, Murthy LN, Mathew S, Venkateshwarlu G, Ravishankar CN. 2016. Nutritional profiling of the edible seaweeds Gracilaria edulis, Ulva lactuca and Sargassum sp. Indian Journal of Fisheries. 63(3): 81-87.

Diachanty S, Nurjanah, Abdullah A. 2017. Aktivitas antioksidan berbagai jenis rumput laut cokelat dari perairan Kepulauan Seribu. Jurnal Pengolahan Hasil Perikanan Indonesia. 20(2): 305318.

Ma’ruf WF, Ibrahim R, Dewi EN, Susanto E, Amalia U. 2013. Profil rumput laut Caulerpa racemosa dan Gracilaria verrucosa sebagai edible food (Caulerpa racemosa and Gracilaria verrucosa profile as edible foods). SAINTEK PERIKANAN: Indonesian Journal of Fisheres Science and Technology. 9(1):68-74. 
Gazali M,Nurjanah N, Zamani NP. 2018. Eksplorasi senyawa bioaktif alga cokelat Sargassum sp. Agardh sebagai antioksidan dari Pesisir Barat Aceh. Jurnal Pengolahan Hasil Perikanan Indonesia. 21(1):167-187.

Hardouin K, Burlot AS, Umami A, Tanniou A, Stiger-Pouvreau V, Widowati I, Bedoux G, Bourgougnon N. 2014. Biochemical and antiviral activities of enzymatic hydrolysates from different invasive French seaweeds. Journal of Applied Phycology. 26(2): 1029-1042.

Harnedy PA, Fitz Gerald RJ. 2011. Bioactive proteins, peptides, and amino acids from macroalgae. Journal of Phycology. 47(2): 218-232.

Hegdekar N, Lipinski MM, Sarkar C. 2021. $\mathrm{N}$-Acetyl-l-leucine improves functional recovery and attenuates cortical cell death and neuroinflammation after traumatic brain injury in mice. Scientific Reports. 11(1): 1-13.

Jacoeb AM, Asnita L, Lingga B. 2012. Karakteristik protein dan asam amino daging rajungan (Portunus pelagicus) akibat pengukusan. Jurnal Pengolahan Hasil Perikanan Indonesia. 15(2): 156163.

Jiang WD, Qu B, Feng L, Jiang J, Kuang SY, Wu P, Tang L, Tang WN, Zhang YA, Zhou XO, Liu Y. 2016. Histidine prevents $\mathrm{Cu}-$ induced oxidative stress and the associated decreases in mRNA from encoding tight junction proteins in the intestine of grass carp (Ctenopharyngodon idella). PLoS One. 11(6): 1-19.

Kadam SU, Álvarez C, Tiwari BK, O'Donnell CP. 2015. Extraction of biomolecules from seaweeds. Di dalam: Seaweed Sustainability. San Diego (US): Academic Press.

Kazir M, Abuhassira Y, Robin A, Nahor O, Luo J, Israel A, Golberg A, Livney YD. 2018. Extraction of proteins from two marine macroalgae, Ulva sp. and Gracilaria sp., for food application, and evaluating digestibility, amino acid composition and antioxidant properties of the protein concentrates. Food Hydrocolloids. 87: 194203.
Kim DH, Kim SH, Jeong WS, Lee HY. 2013. Effect of BCAA intake during endurance exercises on fatigue substances, muscle damage substances, and energy metabolism substances. Journal of Exercise Nutrition and Biochemistry.17(4):169-180.

Kopec W, Jamroz D, Wiliczkiewicz A, Biazik E, Pudlo A, Korzeniowska M, Skiba T. 2020. Antioxidative characteristics of chicken breast meat and blood after diet supplementation with carnosine, L-histidine, and $\beta$-alanine. Antioxidants. 9(11): 1093.

Lumbessy SY, Andayani S, Nursyam H, Firdaus M. 2019. Biochemical study of amino acid profile of Kappaphycus alvarezii and Gracilaria salicornia seaweeds from Gerupuk Waters, West Nusa Tenggara (NTB). EurAsian Journal of BioSciences. 13(1): 303-307.

Manteu SH, Nurjanah, Nurhayati T. 2018. Karakteristik rumput laut cokelat (Sargassum policystum dan Padina minor) dari perairan Pohuwato Provinsi Gorontalo. Jurnal Pengolahan Hasil Perikanan Indonesia. 21(3): 396-405.

Mao X, Zeng X, Qiao S, Wu G, Li D. 2011. Specific roles of threonine in intestinal mucosal integrity and barrier function. Frontiers in Bioscience (Elite edition). 3(4): 1192-200.

Matsui R, Honda R, Kanome M, Hagiwara A, Matsuda Y, Togitani T, Ikemoto N, Terashima M. 2018. Designing antioxidant peptides based on the antioxidant properties of the amino acid side-chains. Food Chemistry. 245: 750755.

McAllan L, Cotter PD, Roche HM, Korpela R, Nilaweera KN. 2013. Impact of leucine on energy balance. Journal of Physiology and Biochemistry. 69(1): 155-163.

Mišurcová L, Buňka F, Ambrožová JV, Machů L, Samek D, Kráčmar S. 2014. Amino acid composition of algal products and its contribution to RDI. Food chemistry. 151:120-125.

Sulaiman MR, Fisal A, Azwan A, Chye FY, Matanjun P. 2015. Crude proteins, total 
soluble proteins, total phenolic contents and SDS-PAGE profile of fifteen varieties of seaweed from Semporna, Sabah, Malaysia. International Food Research Journal. 22(4): 1483-1493.

Morris CR, Hamilton-Reeves J, Martindale RG, Sarav M, Ochoa Gautier JB. 2017. Acquired amino acid deficiencies: a focus on arginine and glutamine. Nutrition in Clinical Practice. 32:30S-47S.

Nufus C, Nurjanah, Abdullah A. 2017. Karakteristik rumput laut hijau dari Perairan Kepulauan Seribu dan Sekotong Nusa Tenggara Barat sebagai antioksidan. Jurnal Pengolahan Hasil Perikanan Indonesia. 20(3): 620-632.

Pangestuti R, Kim S. 2015. Seaweed proteins, peptides, and amino acids. Di dalam: Seaweed Sustainability. San Diego (US): Academic Press.

Peng Y, Xie E, Zheng K, Fredimoses M, Yang X, Zhou X, Liu Y. 2013. Nutritional and chemical composition and antiviral activity of cultivated seaweed Sargassum naozhouense. Marine Drugs. 11(1):20-32.

Pratama RI, Rostini I, Rochima E. 2018. Profil asam amino, asam lemak dan komponen volatil ikan gurame segar (Osphronemus gouramy) dan kukus. Jurnal Pengolahan Hasil Perikanan Indonesia. 21(2): 218231.

Purwaningsih S, Deskawati E. 2020. Karakteristik dan aktivitas antioksidan rumput aut Gracilaria sp. asal Banten. Jurnal Pengolahan Hasil Perikanan Indonesia. 23(3):503-512 .

Purwaningsih S, Salamah E, Apriyana GP. 2013. Profil protein dan asam amino keong ipong-ipong (Fasciolaria salmo) pada pengolahan yang berbeda. Jurnal Gizi dan Pangan. 8(1): 77-82.

Rasyid A, Ardiansyah A, Pangestuti R. 2019. Nutrient composition of dried seaweed Gracilaria gracilis. ILMU KELAUTAN: Indonesian Journal of Marine Sciences. 24(1): 1-6.

Ripps H, Shen W. (2012). taurine: A "very essential" amino acid. Molecular vision. 18: 2673-2686.
Seca AM, Pinto D. 2018. Overview on the antihypertensive and anti-obesity effects of secondary metabolites from seaweeds. Marine Drugs.16 (7): 237

Sena CM, Pereira AM, Seiça R. 2013. Endothelial dysfunction-a major mediator of diabetic vascular disease. Biochimica et Biophysica Acta (BBA)Molecular Basis of Disease.1832(12): 2216-2231.

Shu X, Kang K, Zhong JS, Zhang Y, Hu H, Zhang D. 2014. Meta-analysis of branched chain amino acid-enriched nutrition to improve hepatic function in patients undergoing hepatic operation. Chinese Journal of Hepatology. 22(1): 43-47.

Song J, Liu C, Li D, Gu Z. 2013. Evaluation of sugar, free amino acid, and organic acid compositions of different varieties of vegetable soybean (Glycine max [L.] Merr). Industrial Crops and Products. 50: 743-749.

Theis N, Brown MA, Wood P, Waldron M. 2021. Leucine supplementation increases muscle strength and volume, reduces inflammation, and affects wellbeing in adults and adolescents with cerebral palsy. The Journal of Nutrition.151(1): 59-64.

Utari DM, Rimbawan R, Riyadi H, Muhilal M, Purwantyastuti P. 2011. Potensi asam amino pada tempe untuk memperbaiki profil lipid dan diabetes mellitus. Jurnal Kesehatan Masyarakat (National Public Health Journal).5(4): 166-170.

Vieira EF, Soares C, Machado S, Correia M, Ramalhosa MJ, Oliva-Teles MT, Delerue-Matos C. 2018. Seaweeds from the Portuguese coast as a source of proteinaceous material: Total and free amino acid composition profile. Food Chemistry. 269: 264-275.

Wamiti J, Kogi-makau W, Ngala S, Onyango FE. 2018. Effectiveness of leucine supplementation in the management of moderate wasting in children. $S M$ Journal of Food and Nutritional Disorders. 4(1):1023.

Water . 2012. Acquity UPLC H-Class and H-C lass Bio Amino Acid Analysis System 
Guide. Waters Corporation, Revision C Yaich H, Garna H, Besbes S, Paquot M, Blecker C, Attia H. 2011. Chemical composition and functional properties of Ulva lactuca seaweed collected in Tunisia. Food chemistry. 128(4): 895-901.
Yang QQ, Zhang CQ, Chan ML, Zhao DS, Chen JZ, Wang Q, Liu QQ. 2016. Biofortification of rice with the essential amino acid lysine: molecular characterization, nutritional evaluation, and field performance. Journal of Experimental Botany. 67(14): 4285-4296. 